\title{
Farligt, farligt
}

Ifølge Store norske leksikon ble spiral første gang beskrevet i 1909 i Tyskland, i en tid da det ikke «var akseptert å forskrive noen form for prevensjon». I 1929 ble nye fors $\varnothing k$ beskrevet. I Tidsskriftet advarte man allerede i 1926 (Tidsskr Nor Lægeforen 1926; 46: 1182-4) mot bruken av «sterilet».

\section{Dødelig forløpende sepsis ved bruk av sterilet.}

Av Haakon Bjørn-Hansen, 1ste assistent.

Efter den strenge kritik, som er reist av Brandt, Harald Natvig, Gammeltoft m. fl. mot bruken av sterilet, skulde man tro, at dette instrument var banlyst blandt de midler som av læger brukes for at hindre konception. Det er jo tilfulde bevist, at steriletten ikke som oprindelig tænkt hindrer konception, men at den paa et tidlig stadium av svangerskapet fremkalder abort. Herved blir den steriletbærende kvinde stadig utsat for de farer, som gjentagne provocerte aborter kan medføre, bl.a. først og fremst infektion, fra de lette katarralske til de sværeste spetiske endometriter, salpingiter og bækkenperitoniter.

Da steriletten holdes paa plass i uterinhulen derved, at dens to fjærende, sprikende ben trykker sig op mot og ofte ind i uterinvæggen, vil der kunne dannes gnagsaar, hvorfra infektion gjennem parametriets vener og lymfekar vil kunne bre sig og som i foreliggende tilfælde danne utgangspunktet for en dødelig forløpende sepsis.

Denne uterus med sterilet, som her er fotografert, er fra en 38 aar gl. gift kvinde, som den 27de mars 1926 blev indlagt i Ullevaal med. avd. VII for krupøs pneumoni. Hun hadde været frisk til 3 dager før indkomsten, da hun plutselig fik frysning, hold i venstre side av brystet og hoste. Senere medtat almentilstand, tp. mellem 39 og 40, hoste med blodfarvet gult ekspektorat. Over begge lunger utbredt fremmedlyd. I ekspektoratet fandtes stafylo- og streptokokker, men ikke pneumokokker. Hun døde i 5te døgn efter sygdommens begyndelse. Hadde under sykehusopholdet blødning fra vagina, opfattet som menstruation. Ved sektionen, foretat i Ullevaal pat.-anatomiske laboratorium, blev der fundet en sepsis, med masser av abscesser i begge lunger, rikelig vekst av stafylokokker og streptokokker fra hjerteblod, fra milten samt fra abscesserne. (...)

Det er senere blit mig meddelt, at denne sterilet er indlagt av en læge. (...) At steriletten ogsaa brukes av ikke lægekyndige, er utvilsomt: I en av de kirurgiske avdelinger paa Ullevaal kom der nylig ind

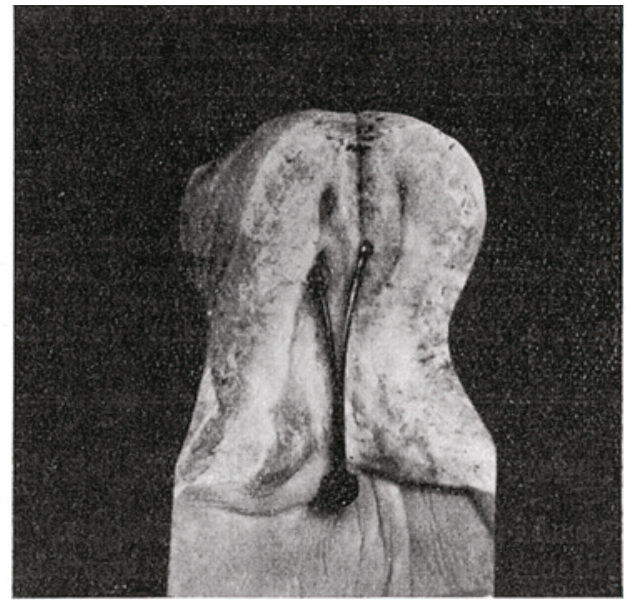

Sterilet $\mathrm{i}$ den opklippede uterus og vagina.

en patient med endometrit, som var kommet i tilslutning til indlæggelse av sterilet av en jordmor for ca. $1 / 2$ aar siden. Endometriten hadde $\mathrm{i}$ denne tid fremkaldt endometrit med kortere og længere febrile perioder, langvarig og pinefuldt sykeleie. Jordmoren hadde efter patientens oplysninger tat 400 kroner for indlæggelsen av steriletten, den skulde nemlig være av rent guld. Patienten gik op til jordmoren og truet med at melde hende, men fik til svar: «Ja værsaagod, bare meld, men De kommer ingen vei, De har ingen vidner og intet skriftlig.» 